\title{
Analisis pengaruh kebijakan bank konvensional terhadap tingkat keuntungan bank syariah
}

\author{
Adina Astasia ${ }^{1}$, You Ari Faeni ${ }^{2}$ \\ ${ }^{1,2}$ Badan Pusat Statistik Kabupaten OKU Timur \\ ${ }^{1}$ adinaastasia@bps.go.id ${ }^{2}$ you@bps.go.id
}

\begin{abstract}
ABSTRAK
Perkembangan perbankan syariah di Indonesia sangat pesat beberapa tahun belakangan ini. Namun, market share perbankan syariah masih jauh di bawah harapan. Kajian-kajian teori sebelumnya menyatakan bahwa lingkungan persaingan antarbank, dalam hal ini bank konvensional dan bank syariah, sangat memengaruhi kinerja bank syariah. Penelitian ini bertujuan mengetahui pengaruh kebijakan bank konvensional yang digambarkan dengan tingkat suku bunga (SB) terhadap keuntungan bank syariah yang digambarkan dengan Return on Assets (ROA). Metode analisis yang digunakan adalah Vector Autoregressive (VAR) dengan tambahan analisis Impulse Response Function (IRF) dan Variance Decomposition Analysis (VDC). Hasil analisis menggunakan VAR (1) menyatakan bahwa terdapat pengaruh negatif signifikan pada keuntungan bank syariah (ROA) jika terjadi shock pada tingkat suku bunga tabungan bank konvensional $(S B)$. Kondisi ini sejalan dengan hasil penelitian Haron dan Ahmad (2000); Haron (2004), serta Zainol dan Kassim (2012) yang mengemukakan bahwa apabila tingkat suku bunga tabungan bank konvensional meningkat, nasabah bank syariah akan beralih ke bank kovensional yang dianggap memberikan keuntungan lebih besar sehingga keuntungan bank syariah mengalami penurunan. Hasil ini menunjukkan bahwa tidak semua konsumen bank syariah merupakan konsumen yang loyalis, perbankan syariah dituntut bertindak rasional, yaitu dengan cara menetapkan tingkat bagi hasil yang kompetitif terhadap tingkat suku bunga bank konvensional.
\end{abstract}

Kata kunci: Bank Syariah, ROA, Tingkat Suku Bunga, Vector Autoregressive

Klasifikasi JEL: G21, G24, G11

\section{ABSTRACT}

The development of Islamic banking in Indonesia had been very rapid in recent years. However, the market share of Islamic banking was still far below expectations. Previous theoretical studies had stated that the competitive environment between conventional banks and Islamic banks, greatly affected the performance of Islamic banks. In this study, we tried to understand how the influence of conventional bank policies which was described by the savings interest rate (SB) towards the profits of Islamic banks described by Return on Assets (ROA). The analysis method used was Vector Autoregressive (VAR) with additional analysis of Impulse Response Function (IRF) and Variance Decomposition Analysis (VDC). The results of the analysis using VAR stated that there was a significant negative effect on Islamic bank profits (ROA) if there was a shock to conventional bank interest rates (SB). This condition was in line with the results of research by Haron and Ahmad (2000); Haron (2004), and Zainol and Kassim (2012) which suggests that if the interest rate for conventional bank savings increases, Islamic bank customers would switch to conventional banks which were considered to provide greater profits, so that the bank's profits will increase, so that the profit of Islamic banks had decreased. These results indicated that not all Islamic bank consumers were loyal consumers, Islamic banking was required to act rationally, namely by setting a competitive profit sharing rate against conventional bank interest rates.

Keywords: Islamic Bank, ROA, Interest Rate, Vector Autoregressive

JEL classification codes: $G 21, G 24, G 11$

\section{PENDAHULUAN}

Dalam beberapa tahun terakhir ini, terjadi goncangan dan ketidakstabilan pada sistem keuangan internasional yang menyebabkan krisis ekonomi. Hal ini diakibatkan oleh sektor finansial yang lebih dominan dibandingkan sektor riil.
Kajian-kajian sebelumnya pun menunjukkan terjadinya laju pertumbuhan perdagangan uang dan derivasinya yang tumbuh hingga sekitar 800 kali lipat dibanding laju pertumbuhan sektor riil (Machmud \& Rukmana, 2009). Hal tersebut 
menunjukkan tidak terintegrasinya kegiatan di sektor riil dengan sektor moneter sehingga muncul berbagai distorsi ekonomi dunia akibat pengaruh dari perilaku ekonomi spekulatif yang kuat serta tidak didasarkan pada kondisi riil potensi ekonomi (Chapra, 2011). Kondisi ini memperlihatkan kurang disiplinnya sistem keuangan yang dapat menjadi akar dari terjadinya krisis global.

Di tengah ancaman krisis global tersebut, perbankan syariah mulai dijadikan alternatif lembaga keuangan yang tahan dalam situasi krisis. Dalam pencarian arsitektur keuangan baru sebagai langkah preventif terhadap krisis selanjutnya, terdapat konsensus bahwa perbankan perlu kembali pada fungsi dasarnya, yaitu menyediakan jasa keuangan yang memiliki nilai tambah pada perekonomian riil. Setiap transaksi harus didasarkan pada aset dasar yang merupakan elemen dasar dari sistem keuangan Islam yang diterapkan pada perbankan syariah. Berbeda dengan perbankan konvensional yang cenderung spekulatif, dalam sistem keuangan Islam, uang hanya digunakan sebagai alat tukar dan menjadi faktor produksi yang dapat berkembang serta menghasilkan nilai lebih melalui investasi ke dalam ekonomi sektor riil sehingga tidak ada unsur spekulatif di dalamnya yang menjadikan adanya ketidakseimbangan antara sektor moneter dan sektor riil.

Perbankan syariah memiliki ketahanan dan kinerja yang lebih baik dalam menghadapi krisis keuangan tahun 2008 dibandingkan dengan perbankan konvensional (Bank Indonesia, 2011). Seperti yang dikemukakan oleh Islamic Development Bank (2010) yang membandingkan kinerja masing-masing 10 top bank konvensional dan bank syariah, diperoleh hasil bahwa selama periode krisis, market capitalisation, aggregate net profits, serta total assets bank syariah menunjukkan kinerja lebih baik dibandingkan bank konvensional. Selain itu, lima dari 10 top bank konvensional menerima bantuan likuiditas dari pemerintah, sementara hanya satu bank syariah yang membutuhkan bantuan pemerintah dan di akhir tahun 2009 tidak satupun bank syariah memperoleh bantuan likuiditas dari pemerintah. Hal ini sejalan dengan penelitian
Salman dan Nawaz (2018) yang menyatakan bahwa perbankan syariah tidak menderita seperti perbankan konvensional saat krisis keuangan global.

Penelitian yang dilakukan Ariss (2010) mengenai kondisi persaingan pada pasar perbankan konvensional dan syariah di 13 negara selama 2000-2006 menunjukkan hasil bahwa perbankan syariah kurang kompetitif dibandingkan perbankan konvensional. Kondisi ini menyebabkan perbankan syariah sulit untuk berkembang dan menguasai pangsa pasar perbankan. Padahal keberadaan dan keunggulan bank syariah baru dapat dirasakan apabila bank syariah telah memiliki porsi yang signifikan dalam tatanan perekonomian nasional. Dengan demikian, maka, pemerintah perlu memberikan perhatian khusus pada perbankan syariah dalam pengembangan sistem dualitas perbankan (dual banking system).

Pengembangan perbankan syariah dalam lingkungan sistem perbankan ganda (dual banking system) tentunya tidak terlepas dari pengaruh bank konvensional (Zainol \& Kassim, 2012). Kebijakan yang dilakukan oleh bank konvensional akan mempengaruhi kinerja bank syariah (Haron \& Ahmad (2000); Haron (2004)). Persaingan antar bank juga mempengaruhi pilihan konsumen perbankan. Beberapa penelitian sebelumnya menyatakan bahwa konsumen jasa perbankan merupakan konsumen rasional, di mana mereka akan memilih bank yang memberikan keuntungan lebih besar bagi mereka (Astasia, 2012). Sejalan dengan penelitian Basheer (2017) dan Zulkhibri (2018) yang menyatakan bahwa suku bunga rendah yang diberikan bank konvensional berdampak positif pada perkembangan bank syariah. Oleh karena itu, penelitian ini bertujuan untuk meneliti dampak kebijakan bank konvensional terhadap tingkat keuntungan bank syariah.

\section{TINJAUAN PUSTAKA}

Tingkat suku bunga merupakan salah satu instrumen kebijakan yang dapat digunakan oleh perbankan, baik dalam upaya menghimpun pendanaan dari pihak ketiga (financing) maupun pembiayaan kepada debitur (lending). Teori klasik 
tentang tingkat suku bunga tabungan menjelaskan bahwa tingkat suku bunga tabungan adalah fungsi dari tingkat bunga, semakin tinggi tingkat bunga maka semakin tinggi keinginan masyarakat untuk menyimpan dana yang dimiliki di bank. Pada tingkat suku bunga tinggi, masyarakat cenderung mengurangi dana untuk konsumsi guna menambah tabungan (Mariantini, 2007). Perubahan tingkat suku bunga berpengaruh signifikan terhadap keuntungan bank yang digambarkan dengan Return on Assets (ROA) dan Return on Equity (ROE) pada perbankan di Pakistan. Sejalan dengan penelitian tersebut, penelitian yang dilakukan Musah, Anokye, dan Gakpetor (2018) pada 24 bank di Ghana menggunakan data panel juga menunjukkan hasil serupa, yaitu tingkat suku bunga berpengaruh signifikan terhadap keuntungan bank.

Berbeda dengan bank konvensional, bank syariah tidak menerapkan instrumen suku bunga, melainkan bagi hasil (profit and loss sharing). Pengertian bagi hasil menurut Antonio (2001) adalah bentuk return dari kontrak investasi, dari waktu ke waktu, tidak pasti, dan tidak tetap. Besar kecilnya perolehan kembali bergantung pada hasil usaha yang benar- benar terjadi. Menurut Zainul Arifin dalam Yahya dan Agunggunanto (2011) teori bagi hasil dikembangkan dalam model mudharabah dan musyarakah. Model mudharabah merupakan kerja sama antara pemilik seluruh modal dengan pengelola dana, sedangkan model musyarakah adalah kerja sama antara kedua pihak atau lebih untuk menjalankan usaha tertentu.

Ariss (2010) melakukan analisis terhadap struktur bank syariah dan konvensional untuk mengetahui perbedaaan keuntungan dari kedua bank di 13 negara selama 2000-2006. Penelitian ini menggunakan univariate statistic dan pengujian dari rata-rata untuk mengetahui portofolio masing-masing bank. Hasil dari penelitian ini menunjukan bahwa bank syariah kurang kompetitif dibandingkan bank konvensional. Padahal dampak positif dari bank syariah baru bisa dirasakan jika bank syariah memiliki pangsa pasar yang besar.

Penelitian mengenai pengembangan pangsa pasar perbankan syariah telah dilakukan dalam beberapa tahun terakhir, di antaranya Astasia (2012) melakukan penelitian mengenai faktorfaktor yang mempengaruhi pangsa pasar bank syariah di Indonesia. Hasil penelitian tersebut adalah deposito mudharabah, proporsi giro wadiah, serta $B I$ rate berpengaruh positif dan signifikan sementara tingkat suku bunga bank konvensional berpengaruh negatif dan signifikan terhadap pangsa pasar bank syariah di Indonesia. Basheer (2017) juga melakukan penelitian serupa mengenai pengaruh customer awareness serta tingkat suku bunga terhadap pertumbuhan islamic banking di Pakistan dengan data primer yang diambil dari 553 responden. Diperoleh hasil bahwa customer awareness serta tingkat suku bunga berpengaruh signifikan terhadap pertumbuhan islamic banking di Pakistan.

Pada teori bejana berhubungan, Karim (2004) mengungkapkan bahwa kebijakan moneter konvensional akan berkaitan dengan perbankan syariah seperti pada tingkat suku bunga. Hal ini disebabkan oleh kebijakan moneter yang mempengaruhi variabel-variabel neraca bank konvensional (suku bunga kredit, suku bunga deposito, dan sekuritas). Ketika bank konvensional menawarkan keuntungan yang lebih rendah maka akan terjadi perpindahan dana dari bank konvensional ke bank syariah.

Beberapa penelitian telah dilakukan untuk mengetahui hubungan kinerja bank syariah dan bank konvensional. Haron dan Ahmad (2000) melakukan penelitian terhadap pengaruh laporan keuntungan bank syariah terhadap jumlah tabungan pada bank syariah yang menunjukan bahwa setiap 1\% peningkatan laporan keuntungan bank syariah akan meningkatkan jumlah tabungan sebesar 90 juta ringgit. Selain itu, peningkatan suku bunga pada bank konvensional juga berpengaruh negatif terhadap jumlah tabungan pada bank syariah.

Zulkhibri (2018) melakukan analisis terhadap kebijakan moneter terhadap keuntungan bank syariah. Penelitian ini menggunakan variabel karakteristik bank syariah dan kebijakan moneter yang diambil di Malaysia menggunakan regresi sederhana dan menghasilkan model hubungan antara aktivitas bank syariah dan kebijakan moneter. 
Berdasarkan tinjauan pustaka di atas, dapat disimpulkan bahwa lingkungan persaingan antar bank, yaitu antara bank syariah dan bank konvensional mempengaruhi perkembangan bank syariah di beberapa negara dengan variabel yang selalu digunakan adalah tingkat suku bunga bank. Analisis yang digunakan pada penelitian sebelumnya menggunakan analisis deskriptif dan regresi. Pada analisis regresi, data deret waktu akan diperlakukan seperti data cross section, sehingga akan kehilangan informasi waktu pada data. Oleh karena itu, pada penelitian ini digunakan analisis deret waktu yaitu Vector Autoregressive (VAR) sehingga akan diperoleh informasi yang lebih mendalam mengenai hubungan antar variabel.

\section{METODE PENELITIAN}

Data yang digunakan dalam penelitian ini merupakan data sekunder yang berasal dari Bank Indonesia bulanan dari bulan Oktober 2014 sampai dengan Desember 2018. Berdasarkan teori yang ada serta keterbatasan data, digunakan variabel tingkat suku bunga tabungan bank umum
$\left(S B_{t}\right)$ untuk menggambarkan kebijakan bank konvensional serta Return on Assets Bank Syariah $\left(R O A_{t}\right)$ untuk menggambarkan keuntungan bank syariah (Rianto, 2012). ROA dihitung dengan membagi total profit dengan total seluruh aset yang ada. ROA menilai kemampuan bank berdasarkan penghasilan keuntungan masa lalu supaya dapat dimanfaatkan untuk membuat kebijakan periode selanjutnya (Petersen \& Schoeman, 2008).

Data diolah menggunakan Software R dengan tambahan package vars dan tseries. Tingkat suku bunga bank umum dan ROA bank syariah dianalisis menggunakan Vector Autoregressive (VAR) dengan tambahan analisis Impulse Response Function (IRF) dan Variance Decomposition Analysis (VDC). Analisis VAR dipilih karena data merupakan data deret waktu yang memiliki hubungan korelasi tinggi antar variabel penelitian. Sebelum analisis menggunakan VAR, data diperiksa korelasinya. Jika memang terdapat korelasi maka VAR dapat dilanjutkan. Gambar 1 menunjukan alur penelitian yang dilakukan dalam penelitian ini. Proses penelitian lebih lengkap akan dijelaskan lebih dalam pada bab hasil dan diskusi.

\begin{tabular}{|l|l|}
\hline 1 & -Periksa Korelasi antar variabel penelitian \\
\hline & -Uji kestasioneran dengan plot time series dan uji ADF \\
\hline 4 & - Lakukan Estimasi Model VAR \\
\hline 6 & $\begin{array}{l}\text { - Analisis IRF untu mendeteksi respon saat ini dan masa depan dari setiap variabel akibat } \\
\text { perubahan variabel alinya }\end{array}$ \\
\hline 7 & $\begin{array}{l}\text {-Analisis VDC untuk memprediksi kontribusi persentase varian setiap variabel karena adanya } \\
\text { perubahan variabel tertentu }\end{array}$ \\
\hline
\end{tabular}

Sumber: Hasil olahan penulis

Gambar 1. Diagram Alur Penelitian 


\section{Uji Kestasioneran}

Langkah awal yang harus dilakukan sebelum melakukan estimasi persamaan regresi menggunakan data time series adalah menguji kestasioneran data. Jika data tidak stasioner maka perilaku data hanya dapat dipelajari sepanjang periode tersebut. Konsekuensinya, tidak mungkin untuk menggeneralkan studi pada suatu periode ke periode lainnya. Oleh karena itu, stasioneritas merupakan salah satu prasyarat penting dalam model ekonometrika untuk data time series.

Data yang stasioner memiliki rata-rata, varians, dan autokovarians tetap sama pada waktu kapan saja data itu dibentuk atau dipakai, disebut time invariant (Gujarati, 2004). Salah satu konsep formal yang dipakai untuk mengetahui kestasioneran data adalah melalui uji akar unit (unit root test). Misalkan terdapat data series dengan persamaan sebagai berikut:

$Y_{t}=\rho Y_{t-1}+u_{t} ; \quad-1 \leq \rho \leq 1$

dimana:

$Y_{t} \quad$ : variabel yang diamati pada periode $\mathrm{t}$

$Y_{t-1}$ : variabel yang diamati pada periode t-1

$\rho \quad:$ koefisien autoregresif

$u_{t}$ : white noise error term $\left(u_{t} \sim N\left(0, \sigma^{2}\right)\right)$.

Jika $\rho=1$, maka terjadi unit root process, yang mencirikan data tidak stasioner. Oleh karena itu untuk menguji stasioneritas data dilakukan regresi sederhana $Y_{t}$ pada nilai lag-nya, $Y_{t-1}$, dan menguji apakah $\rho$ secara statistik sama dengan 1. Jika tolak $\mathrm{H}_{0}$, maka tidak stasioner. Inilah ide umum dibalik unit root test of stationarity.

David Dickey dan Wayne Fuller dalam Dickey-Fuller (DF) test memanipulasi persamaan (2) dengan mengurangkan $Y_{t-1}$ pada kedua sisi, menjadi:

$Y_{t}-Y_{t-1}=\rho Y_{t-1}-Y_{t-1}+u_{t} ; \quad Y_{t}-Y_{t-1}=\Delta Y_{t}$

$\Delta Y_{t}=(\rho-1) Y_{t-1}+u_{t}$

$\Delta Y_{t}=\delta Y_{t-1}+u_{t} ; \quad \delta=(\rho-1)$

DF test mempunyai satu asumsi penting yaitu error $\left(u_{t}\right)$ tidak berkorelasi, padahal pada umumnya $u_{t}$ berkorelasi. Oleh karenanya, dalam penelitian ini digunakan Augmented DickeyFuller (ADF) test (Fuller, 1996) yang merupakan pengembangan dari $D F$ test. Pada $A D F$ test, lag dari difference $\left(\sum_{\mathrm{i}}^{\mathrm{m}}={ }_{1} a_{i} \Delta Y_{t-\mathrm{i}}\right)$ dimasukkan dalam persamaan untuk mengantisipasi adanya autokorelasi pada error. Persamaan ADF test ditulis sebagai berikut:

$\Delta Y_{t}=\delta Y_{t-1}+\sum_{\mathrm{i}}^{\mathrm{m}}={ }_{1} a_{t} \Delta Y_{t-\mathrm{i}}+\varepsilon_{\mathrm{t}}$

dengan $\varepsilon_{t}$ merupakan white noise error

$\left(\varepsilon_{\mathrm{t}} \sim \mathrm{N}\left(0, \sigma^{2}\right)\right)$. Pengujian dilakukan dengan hipotesis:

$\mathrm{H}_{\mathrm{o}}: \delta=0$

(terdapat unit root, data tidak stasioner)

$\mathrm{H}_{1}: \delta<0$

(tidak terdapat unit root, data stasioner)

\section{Vector Autoregressive (VAR)}

Vector Autoregressive (VAR) merupakan sebuah metode estimasi yang dikembangkan oleh Christoper A. Sims tahun 1980 dan merupakan pengembangan dari Autoregression (AR) yang merupakan model univariat. Model VAR merupakan sistem persamaan yang memperlihatkan setiap variabel merupakan fungsi linier dari konstanta dan nilai lag (masa lampau) variabel itu sendiri dan variabel lain dalam persamaan. Seluruh variabel dalam VAR merupakan variabel endogen, tidak ada pembeda antara variabel endogen dan eksogen.

Secara umum, model VAR (1) dalam penelitian ini dapat ditulis sebagai berikut.

$R O A_{t}=\Phi_{11} R O A_{t-1}+\Phi_{12} S B_{t-1}+a_{1 t}(4)$

$S B_{t}=\phi_{21} S B_{t-1}+\Phi_{22} R O A_{t-1}+a_{2 t}$

Identifikasi model dapat dilakukan menggunakan grafik Partial Autocorrelation Function (PACF), jika terpotong menunjukkan model VAR dapat digunakan dengan lag tertentu. Setelah itu stabilitas sistem VAR dilihat dari nilai inverse roots karakteristik AR polinomialnya. Hal ini dapat dilihat dari nilai modulus AR roots-nya. Jika seluruh nilai AR Roots di bawah satu, maka sistem tersebut stabil. Taksiran parameter menggunakan Metode Kuadrat Terkecil. Terdapat tiga analisis VAR yang digunakan dalam penelitian ini, yaitu: Granger Causality, pengujian Granger Causality digunakan untuk menguji hubungan kausalitas antar variabel dalam VAR; Impulse Response Function (IRF), analisis Impulse 


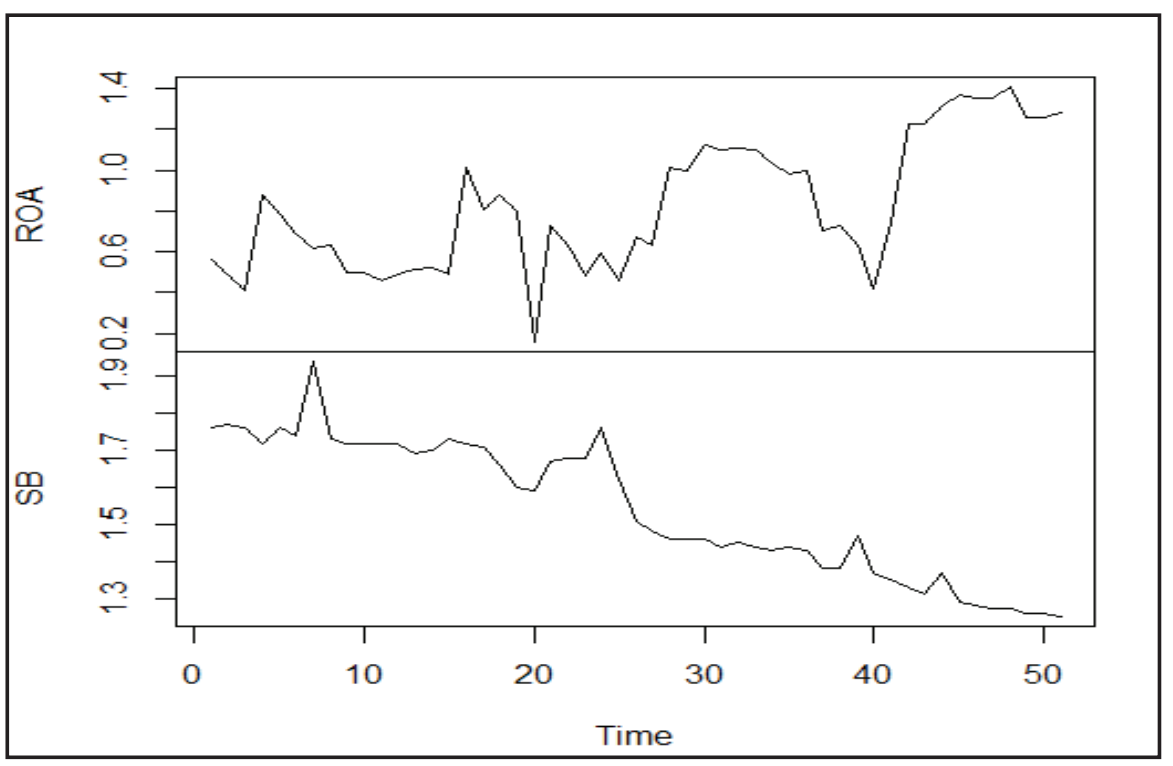

Sumber: Bank Indonesia (2014-2018), diolah

Gambar 2. Plot Tingkat Suku Bunga Tabungan Bank Konvensional () dan Return on Assets () Bank Syariah di Indonesia Bulan Oktober 2014-Desember 2018

Response Function (IRF) berfungsi untuk mendeteksi respons saat ini dan masa depan dari setiap variabel akibat perubahan atau shock dari variabel lainnya. Shock yang diberikan biasanya sebesar satu standar deviasi dari variabel, disebut innovations. Melalui analisis tersebut juga dapat dilihat, setelah terjadi shock pada suatu variabel apakah variabel tersebut dapat kembali kepada titik keseimbangannya dan berapa lama periode yang dibutuhkan untuk kembali ke titik keseimbangan tersebut; Variance Decomposition Analysis (VDC), bertujuan untuk memprediksi kontribusi persentase varian setiap variabel karena adanya perubahan variabel tertentu dalam sistem VAR.

\section{HASIL DAN DISKUSI}

\section{Korelasi Antarvariabel Penelitian}

Sebelum melangkah ke model VAR, langkah pertama yang dilakukan adalah pengujian korelasi antarvariabel, diperoleh hasil korelasi $R O A$ dan $S B$ adalah $-73,41 \%$. Hal ini dapat diartikan bahwa terdapat korelasi tinggi dan negatif antara tingkat suku bunga tabungan bank konvensional $\left(S B_{t}\right)$ dengan keuntungan bank syariah $\left(R O A_{t}\right)$, yaitu sebesar $73,41 \%$. Hal ini sejalan dengan penelitian Haron dan Ahmad (2000) dan Haron (2004) yang menyatakan bahwa nasabah perbankan bersifat rasional, mereka akan cenderung memilih bank yang memberikan keuntungan lebih besar, dengan mempertimbangkan tingkat suku bunga bank konvensional ataupun tingkat bagi hasil bank syariah. Oleh karena itu, tingkat suku bunga sangat menentukan pilihan nasabah dalam menanamkan dana mereka. Jika tingkat suku bunga tabungan bank konvensional lebih rendah, nasabah akan beralih ke bank syariah yang lebih memberikan keuntungan dan sebaliknya. Peningkatan dana yang ditanamkan di bank syariah tentunya akan juga memengaruhi keuntungan bank syariah yang digambarkan dengan peningkatan Return on Assets (ROA) bank syariah.

\section{Hasil Uji Kestasioneran}

Kestasioneran data dapat dilihat melalui plot time series masing-masing data (Gambar 2). Dilihat dari plot data, baik $R O A_{t}$ maupun $S B_{t}$ berada di sekitar rata-rata dengan varians yang cenderung tetap sehingga dapat disimpulkan dari plot bahwa data telah stasioner. Namun, jika hanya dilihat dari plot akan menimbulkan multiinterpretasi sehingga data akan diuji secara formal melalui uji ADF.

Pengujian formal mengenai stasioneritas dilakukan melalui Augmented Dickey-Fuller test (uji ADF). Pengujian dilakukan menggunakan software R package tseries, dengan hasil sebagai berikut: 
Tabel 1. Hasil Uji ADF terhadap Tingkat Suku Bunga Tabungan Bank Konvensional $\left(S B_{t}\right)$ dan Return on Assets $\left(R O A_{t}\right)$ Bank Syariah

\begin{tabular}{lll}
\hline Variabel & p-value & Kesimpulan \\
\hline$R O A_{t}$ & 0,02392 & Stasioner \\
\hline$S B_{t}$ & 0,02373 & Stasioner \\
\hline Sumber: Hasil olahan penulis &
\end{tabular}

Pada uji ADF dapat dilihat bahwa $p$-value kedua variabel sebesar 0,02392 dan 0,02373. Karena nilai $p$-value lebih kecil dari $\alpha$ yang digunakan yaitu $5 \%$, dapat disimpulkan bahwa data tersebut telah stasioner. Berdasarkan pengujian di atas, dapat disimpulkan bahwa data stasioner. Dapat juga diartikan bahwa tingkat suku bunga bank konvensional $\left(S B_{t}\right)$ serta Return on Assets $\left(R O A_{t}\right)$ bank syariah merupakan time invariant dan pengujian menggunakan analisis time series VAR dapat dilakukan (Johansen, 1995).

\section{Identifikasi Model}

Identifikasi model apakah data dapat dikerjakan menggunakan VAR dapat diketahui melalui plot Partial Autocorrelation Function (PACF) (Gambar 3).
Dari hasil PACF pada Gambar 3 dapat dilihat bahwa kedua variabel sama-sama memotong di lag 1 dan tidak memotong di lag lainnya sehingga model yang sesuai adalah VAR (1). Setelah itu dihitung stabilitas sistem VAR yang dilihat dari nilai modulus AR roots-nya, dengan hasil 0,9688 dan 0,4749. Karena seluruh nilai AR Roots di bawah satu, maka sistem tersebut stabil sehingga pemodelan VAR dapat dilanjutkan.

\section{Model VAR (1)}

Berdasarkan hasil identifikasi model menggunakan PACF didapatkan model yang sesuai adalah model VAR(1). Estimasi Model VAR(1) berarti bahwa suatu variabel tidak hanya dipengaruhi variabel masa lalunya tetapi dipengaruhi juga oleh masa lalu variabel lain. Pemodelan dilakukan menggunakan software $R$ package vars, dengan hasil sebagai berikut:

Tabel 2. Pemodelan VAR Tingkat Suku Bunga Tabungan Bank Konvensional (SB) dan Return on Assets (ROA) Bank Syariah

\begin{tabular}{lllll}
\hline Variabel & Koefisien & Standar Eror & t-value & p-value \\
\hline Model untuk $\boldsymbol{R O} \boldsymbol{A}$ & & & \\
\hline$R O A_{t-1}$ & 0,5315 & 0,1194 & 4,453 & $5,25 \times 10^{-5^{*}}$ \\
\hline$S B_{t-1}$ & $-0,6492$ & 0,2080 & $-3,121$ & $0,00307^{*}$ \\
\hline konstanta & 1,4027 & 0,3992 & 3,514 & $0,000988^{*}$ \\
\hline Model untuk $\boldsymbol{S B}$ & & & \\
\hline$R O A_{t-1}$ & $-0,03810$ & 0,03831 & $-0,995$ & 0,325 \\
\hline$S B_{t-1}$ & 0,91225 & 0,06676 & 13,665 & $2 \times 10^{-16^{*}}$ \\
\hline konstanta & 0,15685 & 0,12812 & 1,224 & 0,227 \\
\hline
\end{tabular}

${ }^{{ }^{*}}$ signifikan pada taraf nyata $5 \%$

Sumber: Hasil Olahan Penulis

Berdasarkan hasil pemodelan di atas, diperoleh model VAR(1) sebagai berikut:

$$
\begin{aligned}
& \left.\widehat{\left(R O A_{t}\right.}\right)=0.5315 R O A_{t-1}-0.6492 S B_{t-1}+1.4027 \\
& \left(\widehat{S B}_{t}\right)=0.91225 S B_{t-1}-0.03810 R O A_{t-1}+0.15685
\end{aligned}
$$




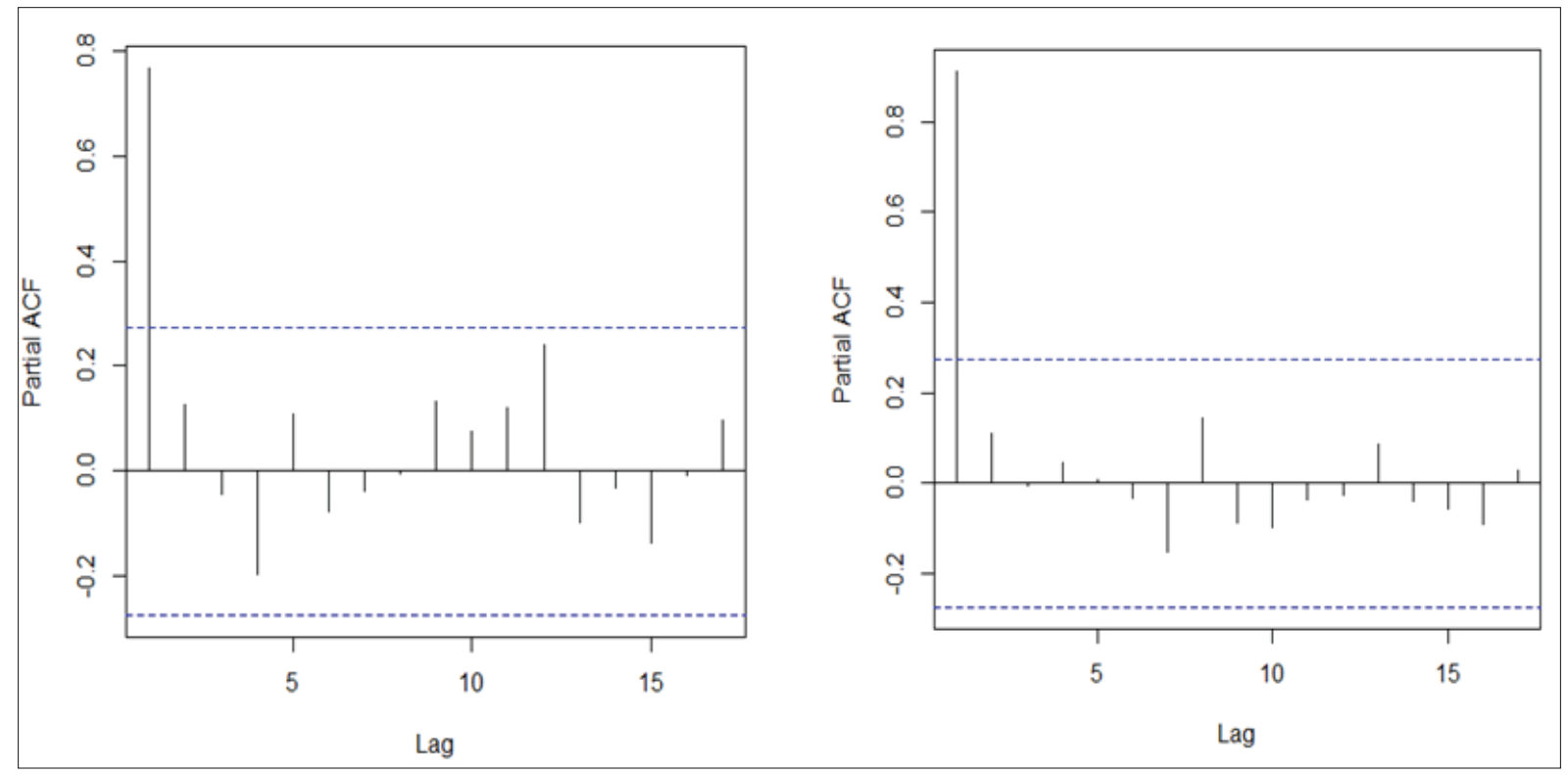

Sumber: Hasil olahan penulis

Gambar 3. Partial Autocorrelation Function (PACF) variabel $S B$ dan $R O A$

Model pada persamaan (5) yang menjelaskan bahwa ROA bank syariah pada suatu periode $\left(R O A_{t}\right)$ dipengaruhi secara signifikan oleh ROA bank syariah periode sebelumnya $\left(R O A_{t-1}\right)$ serta tingkat suku bunga tabungan bank konvensional periode sebelumnya $\left(S B_{t-1}\right)$ merupakan model yang fit dan dapat menjelaskan $R O A_{t}$ sebesar $67,46 \%$. Terdapat hubungan signifikan positif antara keuntungan bank syariah periode sebelumnya $\left(R O A_{t-1}\right)$ dengan tingkat keuntungan bank syariah periode saat ini $\left(R O A_{t}\right)$, dengan koefisien sebesar 0,5315 artinya kenaikan ROA periode sebelumnya sebesar 1 satuan akan mengakibatkan kenaikan ROA periode saat ini sebesar 0,5315 satuan dengan asumsi variabel lain konstan.

Hal yang menarik pada Persamaan (5) di atas adalah adanya hubungan negatif dan signifikan antara ROA bank syariah $\left(R O A_{t}\right)$ dan tingkat suku bunga tabungan bank konvensional $\left(S B_{t-1}\right)$ dengan koefisien sebesar 0,6492 . Hal ini sejalan dengan teori yang ada bahwa jika terjadi kenaikan tingkat suku bunga tabungan bank konvensional sebesar $1 \%$ pada periode sebelumnya $\left(S B_{t-1}\right)$ akan menyebabkan penurunan ROA bank syariah sebesar 0,6492 satuan dengan asumsi variabel lain konstan. Hasil ini semakin memperkuat pernyataan bahwa kenaikan tingkat suku bunga tabungan bank konvensional menyebabkan nasabah mengalihkan dananya ke bank konvensional sehingga dana di bank syariah menurun yang juga memengaruhi tingkat keuntungannya (ROA). Hal ini sejalan dengan penelitian Haron \& Ahmad (2000) sebelumnya bahwa tidak semua konsumen bank syariah merupakan konsumen yang loyalis, mereka akan cenderung memilih menempatkan dananya pada bank yang memberikan keuntungan lebih besar, dengan tingkat suku bunga/tingkat bagi hasil terbesar.

Sementara itu, model pada persamaan (6) menjelaskan bahwa tingkat suku bunga tabungan bank konvensional $\left(S B_{t-1}\right)$ serta ROA bank syariah periode sebelumnya $\left(R O A_{t-1}\right)$ merupakan model yang fit yang dapat menjelaskan $S B_{t}$ sebesar $89,79 \%$. Terdapat hubungan signifikan positif antara tingkat suku bunga tabungan bank konvensional periode sebelumnya $\left(S B_{t-1}\right)$ dengan tingkat suku bunga tabungan bank konvensional periode saat ini $\left(S B_{t}\right)$ dengan koefisien sebesar 0.91225 artinya kenaikan $S B_{t-1}$ sebesar 1\% akan mengakibatkan kenaikan $S B_{t}$ sebesar $0.91225 \%$ dengan asumsi variabel lain konstan. Sementara hubungan antara $S B_{t}$ dengan $R O A_{t-1}$ negatif, namun tidak signifikan.

Setelah pemodelan VAR(1), dilakukan pengujian Granger Causality dengan hasil variabel tingkat suku bunga bank konvensional $\left(S B_{t}\right)$ dan keuntungan bank syariah $\left(R O A_{t}\right)$ menunjukkan hubungan kausalitas. Hal ini semakin memperkuat output model VAR(1) di 


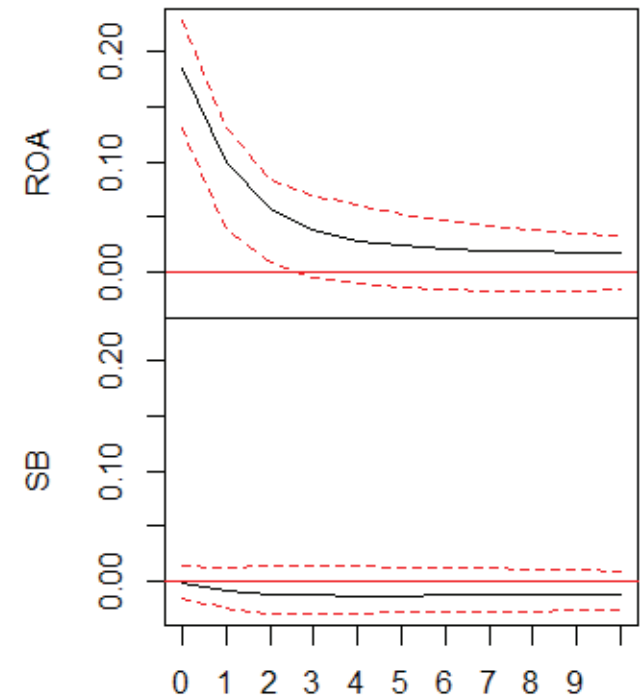

$95 \%$ Bootstrap $\mathrm{Cl}, 100$ runs

(a)

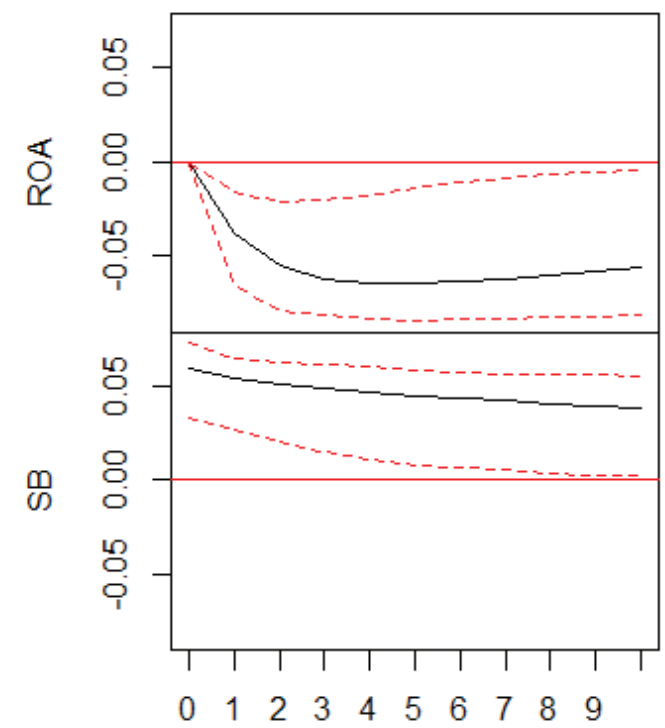

$95 \%$ Bootstrap Cl, 100 runs

(b)

Sumber: Hasil Olahan Penulis

Gambar 4. Impulse Response Function (IRF) variabel penelitian

atas sehingga dapat dilakukan analisis selanjutnya yaitu Impulse Response Function (IRF) serta Variance Decomposition Analysis (VDC).

\section{Impulse Response Function (IRF)}

Analisis Impulse Response Function (IRF) berfungsi untuk mendeteksi respons saat ini dan masa depan dari setiap variabel akibat perubahan atau shock dari variabel lainnya (Gambar 4).

Gambar 4(a) menunjukkan respons bank syariah dan tingkat suku bunga tabungan bank konvensional $(S B)$ jika terjadi shock pada bank syariah. Dapat dilihat bahwa respons terhadap shock yang terjadi pada menunjukkan kondisi positif, artinya shock pada menyebabkan respons positif atau kenaikan pada periode selanjutnya dengan pengaruh yang memiliki kecenderungan semakin menurun seiring waktu. Sementara respons SB terhadap shock yang terjadi pada menunjukkan kondisi negatif dan tidak signifikan terlihat dari grafik yang landai.
Gambar 4(b) menunjukkan respons bank syariah dan tingkat suku bunga tabungan bank konvensional $(S B)$ jika terjadi shock atau perubahan pada tingkat suku bunga tabungan bank konvensional $(S B)$. Dapat dilihat bahwa respons terhadap shock yang terjadi pada $S B$ menunjukkan kondisi negatif, berarti apabila terjadi shock pada tingkat suku bunga tabungan bank konvensional $(S B)$ maka ROA bank syariah periode selanjutnya akan memberikan respons negatif berupa penurunan dengan dampak signifikan ditandai dengan grafik yang berubah tajam pada. Sementara pengaruh shock $S B$ terhadap $S B$ periode selanjutnya menunjukkan kondisi positif dan signifikan.

\section{Variance Decomposition Analysis (VDC)}

Variance Decomposition Analysis (VDC) bertujuan untuk memprediksi kontribusi persentase varian setiap variabel karena adanya perubahan variabel tertentu dalam sistem VAR. 
Tabel 3. Variance Decomposition Analysis (VDC) pada model VAR(1)

\begin{tabular}{|c|c|c|c|c|c|}
\hline Periode & ROA & SB & Periode & ROA & SB \\
\hline \multicolumn{3}{|c|}{ Model ROA } & \multicolumn{3}{|c|}{ Model SB } \\
\hline 1 & 1,0000000 & 0,00000000 & 1 & 0,001082167 & 0,9989178 \\
\hline 2 & 0,9674739 & 0,03252612 & 2 & 0,012517152 & 0,9874828 \\
\hline 3 & 0,9122450 & 0,08775495 & 3 & 0,023995147 & 0,9760049 \\
\hline 4 & 0,8525246 & 0,14747544 & 4 & 0,033298447 & 0,9667016 \\
\hline 5 & 0,7974549 & 0,20254514 & 5 & 0,040419650 & 0,9595804 \\
\hline 6 & 0,7496970 & 0,25030302 & 6 & 0,045822332 & 0,9541777 \\
\hline 7 & 0,7091279 & 0,29087208 & 7 & 0,049960536 & 0,9500395 \\
\hline 8 & 0,6747763 & 0,32522365 & 8 & 0,053182857 & 0,9468171 \\
\hline 9 & 0,6455703 & 0,35442973 & 9 & 0,055738386 & 0,942616 \\
\hline 10 & 0,6205684 & 0,37943162 & 10 & 0,057801499 & 0,9421985 \\
\hline
\end{tabular}

Sumber: Hasil olahan penulis

Berdasarkan hasil variance decomposition pada Tabel 3 terlihat bahwa variabel Return on Assets (ROA) dipengaruhi oleh variabel $R O A$ itu sendiri, namun pengaruhnya semakin menurun sepanjang periode didekomposisi dengan tambahan pengaruh dari tingkat suku bunga bank kovensional $(S B)$ sampai sebesar 37,94\% pada periode ke-10. Sementara hasil variance decomposition dari variabel tingkat suku bunga tabungan bank konvensional $(S B)$ terlihat bahwa variabel $S B$ dipengaruhi oleh variabel $S B$ itu sendiri hampir sepanjang periode. Hasil analisis VDC ini makin memperkuat hasil penelitian bahwa tingkat suku bunga bank kovensional $(S B)$ memiliki pengaruh yang sangat besar terhadap keuntungan bank syariah (ROA), namun tidak berlaku sebaliknya.

\section{KESIMPULAN}

Berdasarkan model VAR(1) dapat disimpulkan bahwa tingkat suku bunga bank konvensional berpengaruh signifikan terhadap keuntungan bank syariah dan menunjukkan hubungan negatif yang kuat. Kondisi ini sesuai dengan teori yang didasari bahwa apabila tingkat suku bunga tabungan bank konvensional $(S B)$ meningkat, akan menyebabkan penurunan keuntungan bank syariah (ROA). Berdasarkan hasil analisis Impulse Response Function (IRF) dan Variance Decomposition
Analysis (VDC), respons keuntungan bank syariah $(R O A)$ terhadap shock tingkat suku bunga tabungan bank konvensional $(S B)$ menunjukkan kondisi negatif yang cukup tajam. Sementara respons $S B$ terhadap shock pada $R O A$ juga negatif namun tidak terlalu besar. Hal ini menunjukkan bahwa tingkat suku bunga bank kovensional $(S B)$ memiliki pengaruh yang sangat besar terhadap keuntungan bank syariah ( $R O A)$, namun tidak berlaku sebaliknya.

Berdasarkan hasil kesimpulan di atas, pengembangan bank syariah harus berorientasi pasar dengan menyesuaikan dengan pengguna jasa perbankan Syariah, yaitu masyarakat. Hal ini karena tidak semua nasabah perbankan, terutama bank syariah yang loyal. Kebanyakan nasabah justru bersifat rasional di mana mereka akan memilih bank yang memberikan keuntungan terbesar bagi mereka, dalam hal ini tingkat suku bunga/tingkat bagi hasil. Oleh karena itu, tingkat bagi hasil bank syariah harus mampu bersaing dengan tingkat suku bunga bank konvensional dengan tetap berpegang pada prinsip-prinsip syariah.

\section{REFERENSI}

Antonio, M. S. (2001). Bank syariah dari teori ke praktek. Gema Insani Press. 
Ariss, R. T. (2010). Competitive conditions in Islamic and conventional banking: A global perspective. Review of Financial Economics, 19(3), 101-108. https://doi.org/10.1016/j. rfe.2010.03.002

Astasia, A. (2012). Faktor-faktor yang mempengaruhi market share perbankan syariah di Indonesia. Sekolah Tinggi Ilmu Statistik.

Bank Indonesia. (2011). Statistik perbankan syariah. Jakarta: Bank Indonesia.

Basheer, M. F. (2017). Impact of customer awareness, competition and interest rate on growth of Islamic banking in Pakistan. International Journal of Scientific \& Technology Research, 6(4), 34-40.

Chapra, M. U. (2011). The global financial crisis: Can Islamic finance help? Dalam Langton J., Trullols C., Turkistani A.Q. (eds), Islamic Economics and Finance, IE Business Publishing. Palgrave Macmillan, London. https://doi.org/10.1057/9780230361133_5

Fuller, W. A. (1996). Introduction to statistical time series. John Wiley.

Gujarati, D. (2004). Basic econometrics (4 ${ }^{\text {th }}$ edition). Tata McGraw Hill.

Haron, S., \& Ahmad, N. (2000). The effects of conventional interest rates and rate of profit on funds deposited with Islamic banking system in Malaysia. International Journal of Islamic Financial Services, 1(4), 1-7.

Haron, S. (2004). Determinants of Islamic bank profitability. Global Journal of Finance and Economics, 1(1).

Islamic Development Bank. (2010). Islamic finance and global financial stability. Islamic Development Bank.

Johansen, S. (1995). Likelihood-based inference in cointegrated vector autoregressive models. Oxford University Press. https://doi. org/10.1093/0198774508.001.0001

Karim, A. (2004). Bank Islam: Analisis fiqih dan keuangan. PT Grafindo Persada.
Machmud, A. \& Rukmana. (2009). Bank syariah: Teori, kebijakan, dan studi empiris di Indonesia. Erlangga.

Mariantini, B. (2007). Analisis pengaruh suku bunga bank konventional terhadap jumlah simpanan pada bank umum syariah tahun 2002-2006. [Unpublished undergraduate thesis]. Institut Pertanian Bogor.

Musah, A., Anokye, F. K., \& Gakpetor, E. D. (2018). The impact of interest rate spread on bank profitability in Ghana. European Journal of Business, Economics, and Accountancy, 6(1), 27-38.

Petersen, M. A., \& Schoeman, I. (2008). Modeling of banking profit via return-on-assets and return-on-equity. Proceedings of the World Congress on Engineering, II, 1-6.

Rianto, N. (2012). Lembaga keuangan syariah. Pustaka Setia.

Salman, A., \& Nawaz, H. (2018). Islamic financial system and conventional banking: A comparison. Arab Economic and Business Journal, 13(2), 155-167. https://doi. org/10.1016/j.aebj.2018.09.003

Yahya, M., \& Agunggunanto, E. Y. (2012). Teori bagi hasil (profit and loss sharing) dan perbankan syariah dalam ekonomi syariah. Jurnal Dinamika Ekonomi Pembangunan, 1(1), 65-73. https://doi.org/10.14710/ jdep.1.1.65-73Zainol, Z., \& Kassim, S. (2012). A critical review of the literature on the rate of return risk in Islamic banks. Journal of Islamic Accounting and Business Research, 3(2), 121-137. https://doi. org/10.1108/17590811211265948

Zulkhibri, M. (2018). The impact of monetary policy on Islamic bank financing: Banklevel evidence from Malaysia. Journal of Economics, Finance and Administrative Science, 23(46), 306-322. https://doi. org/10.1108/JEFAS-01-2018-0011. 